\title{
Creación y desmantelamiento de la iglesia metropolitana de Santo Domingo (1547-1802)
}

\section{M. a MAGDALENA GUERRERO CANO}

A raíz del descubrimiento de América; los Reyes Católicos se plantearon la organización eclesiástica indiana.

Estaba reciente la conquista de Granada, en la que habían tenido que resolver parecida cuestión (1). Para ello se apoyaron en la bula "Ortodoxae Fidei" (2) otorgada por el papa Inocencio VIII el 13 de diciembre de 1486 que les daba el título de Patronos Universales. El mismo tipo de patente se quiso gestionar para Indias.

Pero la "Inter Caetera", concedida por Alejandro VI el 3 de mayo de 1493, sólo otorgaba la misión de enviar evangelizadores a las tierras recién descubiertas, no el Patronato Regio (3).

Por el Breve "Piis Fidelium" de 25 de abril de 1493, se habían concedido amplios poderes a Fray Bernardo Boil y a sus compañeros para acompañar a Colón en su segundo viaje. En La Española se indispuso con Colón, al que excomulgó, y volvió a la península dos años después (4).

Fundadas algunas iglesias, propusieron los Reyes Católicos la creación de obispados que dieran mayor estabilidad a las misiones y pensaron en la erección de la metropolitana de Yaguata y las sufragáneas

(1) HERA, Alberto de la: El Regio Patronato de Granada y las islas Canarias. "Anuario de Historia del Derecho Español". Madrid, 1958, XVII-XVIII, págs. 1-16. GUERRERO CANO, M. Magdalena: El Patronato de Granada y el de Indias: algunos de sus aspectos. En "II Jornadas de Andalucía y América". Escuela de Estudios Hispanoamericanos de Sevilla. Sevilla, 1984, tomo I, págs. 69-90.

(2) PERAZA DE AYALA, José de: El Real Patronato de Canarias. "Anuario de Historia del Derecho Español". Madrid, 1960, XXX, págs. 113-174.

(3) EGAÑA; S.J., Antonio de: La Teoria del Regio Vicariato Español en Indias. "Analecta Gregoriana", vol. XCV. Roma, 1958. Universidad Gregoriana, pág. XXVII.

(4) HERNANDEZ: Colección de Bulas II, 1069. Su transcripción latina en FITA: "Fray Bernal Buyl"; B.R.A.H.M. XIX, págs. 187-190. 
de Magua y Baynúa, todas en La Española. Lo concedió Julio II, el 15 de noviembre de 1504, en "Illius Fultici Praesidio" y confirmó por la "Universalis Eclesiae" que fue la bula institucional del Patronato Real de las Indias (5). Pero estas fundaciones nunca se llevaron a cabo, pues la realidad demostró que eran demasiadas diócesis.

Concedido el Real Patronato, en 1511, siendo papa Julio II, se establecieron dos diócesis en la isla, la de Santo Domingo y la de Concepción de la Vega (6). En 1512 se añadía la de San Juan de Puerto Rico. Y finalmente, pocos años después, en 1528, las dos primeras quedaron unificadas en la de Santo Domingo (7), que dependió de Sevilla hasta 1547 en que se erigió arzobispal siendo pontífice Paulo III (8).

Estos primeros años tras el descubrimiento fueron años de tanteo. Los obispados recién fundados se concibieron como diócesis misioneras, pero el descenso de población india no permitió el desarrollo de éstos.

Además, la mucha distancia que separaba Europa de América y el interés en que las nuevas tierras funcionaran como provincias españolas motivaron el traslado e implantación de instituciones eclesiásticas ya existentes en la península, e impidieron la posible creación de estructuras apropiadas al nuevo medio. El resultado fue el establecimiento de diócesis sin pueblo real al que guiar espiritualmente, y de catedrales metropolitanas en pequeños poblados de simples cobertizos.

Es conveniente subrayar el hecho de que al ser Santo Domingo el primer obispado establecido en Indias, aunque en un principio sufragáneo del de Sevilla, ese origen le diese un gran peso en la evangelización americana. Significación más bien simbólica, en tanto en cuanto no respondía a una situación real. La escasez de población blanca,

(5) Recopilación de leyes de los reynos de las Indias. Mandadas imprimir y publicar por la magestad católica del rey don Carlos II, nuestro señor. En Madrid: Por Julián de Paredes, año de 1681. En Madrid: Por Ediciones Cultura Hispánica, año de 1973. Libro I, Título Sexto: "Del Patronazgo Real de las Indias", págs. 21-30.

(6) PRIEN, Hans-Jürgen: La Historia del cristianismo en América Latina. Ediciones Sigueme, Salamanca (España), 1985, pág. 101.

(7) LOPETEGUI, León y ZUBILIAGA, Félix: Historia de la Iglesia en América Española. Desde el descubrimiento hasta comienzos del siglo XIX. Tomo I (México-América Central-Antillas) BAC. Madrid, 1965.

(8) El Dr. Garrido apoyándose en la coincidencia cronológica de las erecciones de las dos iglesias, la granadina y la indiana, destaca el indudable papel que la primera debió tener en los orígenes de la segunda. Igual o más importante debió ser la repercusión de la sevillana. GARRIDO ARANDA, Antonio: Organización de la Iglesia en el reino de Granada y su proyección en Indias. Escuela de Estudios Hispanoamericanos de Sevilla. Sevilla, 1979. 
el traslado de muchos de sus sacerdotes y frailes a otras zonas de América más prometedoras hizo que la implantación efectiva de la Iglesia en el siglo XVI distase mucho de lo que cabría imaginar.

Como decimos más arriba, una fecha clave en la historia eclesiástica de la isla es la del 1 de febrero de 1546, en que Santo Domingo es desgajado de la jurisdicción metropolitana de Sevilla y se crean tres sedes arzobispales en Indias: Santo Domingo, México y Lima (9).

Este hecho es decisivo porque va a dar a Santo Domingo la condición de iglesia primada de las Indias, título que viene a ser más honorífico que efectivo.

Según el cronista Juan López de Velasco, en su obra "Geografía y descripción universal de las Indias"; del arzobispado de Santo Domingo, en torno a 1571; dependían tres obispados sufragáneos y una abadía: Cuba, San Juan de Puerto Rico y Venezuela y la abadía de Jamaica (10). Al fundarse el arzobispado de Santa Fé pasaron a depender de él, Camayagua en 1564 y Cartagena en 1577.

Antonio Vázquez de Espinosa da cuenta en su "Compendio y descripción de las Indias Occidentales" (1629) de que Santo Domingo sigue con las mismas sufragáneas y abadías, además de "la que nuevamente se ha mandado poner en las provincias de Guayana" (11).

Juan Díez de la Calle en su "Memorial y noticias sacras y reales del Imperio de las Indias Occidentales" (1659) hace depender del arzobispado dominicano, las mismas sedes, además de la de Trinidad (12).

Y Pedro Murillo Valverde en "Geografía Histórica de la isla Española" (1752) dice que son sufragáneas de la sede dominicana: Puerto Rico, Cuba y Honduras (13).

Cabe observar que ya desde el principio va a ser una sede de jurisdicción discutida y que se van a dar una serie de hechos que se van a repetir como constantes: escasez numérica del clero en proporción a los fieles y disparidad entre el clero urbano y el rural, este últi-

(9) MENDIETA, Fray Jerónimo de: Historia Eclesiästica Indiana. Biblioteca de Autores Españoles. Madrid, 1973.

(10) LOPEZ DE VELASCO, Juan: Geografia y descripción universal de las Indias. En "Relaciones Geográficas de Santo Domingo". Sociedad Dominicana de Geografia. Editora del Caribe, C. por A. Santo Domingo, República Dominicana, 1970, pág. 14.

(11) VAZQUEZ DE ESPINOSA, Antonio: Compendio y descripción de las Indias Occidentales. En Ibídem, pág. 51.

(12) DIEZ DE LA CALLE, Juan: Memorial y noticias sacras y reales del Imperio de las Indias Occidentales. En Ibídem, pág. 57.

(13) MURILLO VALVERDE, Pedro: Geografía Histórica de la isla Española. En Ibídem, pág. 105. 
mo sensiblemente más bajo. Esta base es la que explica el pesimismo dominante en los informes eclesiásticos de la época. En el siglo XVI los obispos se quejan del abandono e ignorancia en que está inmersa la isla. A mediados del siglo XVII se anota la existencia de 40 sacerdotes diocesanos, contando en ese número a los 18 de la catedral y de 40 religiosos de las tres órdenes (franciscanos, dominicos y mercedarios), que desde comienzos del siglo XVI estaban establecidos en la isla.

Lo significativo de este periodo para nosotros es que, en líneas generales, la organización de la iglesia dominicana va a perdurar hasta el siglo XIX: una única sede, un cabildo catedral casi siempre inalterable en su estructura interior, aunque en ocasiones tuviese dignidades sin cubrir, una cabeza que no respondía al cuerpo eclesiástico que cubría toda la isla; de ello un desequilibrio en la atención pastoral y un riesgo, y en ocasiones una seguridad de desviaciones en el campo de la vida cristiana.

Este es el trasfondo religioso de una serie de acontecimientos políticos que dan lugar a que el 22 de julio de 1795 se firmara un tratado en Basilea, del que su artículo 9. estipulaba el paso a Francia de la parte española de la isla "con los cañones, municiones de guerra y cuanto hubiese reunido en dicho territorio para su defensa" (14).

El padre Ayala describe así lo sucedido:

"En el año 95 del siglo anterior de 1700, tuvo lugar la cesión de esta isla en la parte oriental a la Francia por cuya causa las familias más pudientes emigraron a los países españoles circunvecinos con todos sus bienes que habían poseído, de donde resultó el quedar arruinadas las haciendas, los hatos de todo género y dispersas las familias por todas partes del hemisferio, por cuya causa, devastadas las ricas poblaciones de esta parte del Este, y de nuestras fronteras, cuyos habitantes abandonaron sus hogares y propiedades para huir aterrorizados de los horrores que los haitianos cometían en la parte francesa" (15).

En el tratado quedaba establecido que en el plazo de un mes desde que se supiera la noticia en la isla, España tenía que desalojar

(14) HOEPELMAN, Virgilio: Historia Cultural y Politica de Santo Domingo. Publicaciones América, Santo Domingo, República Dominicana. 1976.

(15) AYALA GARCIA, Pbro. Juan de Jesús: Desgracias de Santo Domingo. En GARCIA, Lic. Leónidas: "Miscelánea Histórica". En "Clio", XXIV, n.ำ 108 (julio-diciembre, 1956), pág. 141. 
su territorio. Pero Roume de Saint-Laurent, comisario-ciudadano que había tomado posesión en nombre del Comité de Salud Pública, fue aplazando la entrega (16) porque temía que las discordias entre criollos, negros y mulatos de "Saint Domingue" pasaran a la parte española.

El aplazamiento no fue efectivo, porque muchos españoles salieron a toda prisa, sobre todo a Caracas y La Habana (17); e incluso el mismo arzobispo Portillo "que veía su vida pendiente de un hilo" (18) abandonó su archidiócesis, a pesar de las presiones del comisario Roume para que se quedara (19). En su lugar había nombrado como provisor al fiscal de la Audiencia, el presbítero Matías Manuel Gallardo, del que opinaba:

"sujeto que si no está dotado de tan exquisito talento... es el encontrado más a propósito, porque al fin hará cuanto se le mande sin pereza y no sin acierto" (20)

aunque sospechaba que los franceses no respetarian el nombramiento.

El panorama no pudo ser más desolador. Todos los organismos oficiales fueron desmantelados. Incluso la catedral que por su condición de primada parecía ser llamada a constituirse en ejemplo del resto de las iglesias americanas, se vio extinguida.

Se planteaba el problema de la adscripción de las sufragáneas (La Habana, Santiago de Cuba, Puerto Rico, Luisiana, Caracas y Guayana) (21), por lo que el Consejo de Indias, en pleno de tres salas, elevó en 1800 una consulta al Rey sobre la situación en que habían quedado las diócesis sufragáneas de la metropolitana de Santo Domingo, al suprimirse la Mitra por la cesión de la isla a la República francesa.

Habían quedado privadas de legítimo inmediato superior, todas las sufragáneas y los asistentes a la consulta: marqués de Bajamar (Antonio Porlier), Pedro Muñoz de la Torre, Jorge Escobedo, Fernando José Mangino y conde de Pozos Dulces, el 10 de diciembre proponen a su Majestad que el Consejo tratase este asunto y le sugiriese lo más oportuno.

(16) GUERRERO CANO, M.르 Magdalena: La ocupación de Santo Domingo por Saint Domingue, a través de la correspondencia de su Arzobispo. Coloquio "Les Revolutions Iberiques et Ibero-americaines a l"aube du XIXe siécle: "Maison des pays Iberiques. Centre National de la Recherche Scientifique. Université de Bordeaux III.

(17) Archivo General de Indias de Sevilla (AGI), Estado, leg. 11/11 y 11/45.

(18) AGI. Estado, leg. 11/1.

(19) AGI. Estado, leg. 11/11 y $11 / 6$.

(20) AGI. Estado, leg. 11/6.

(21) AGI. Ultramar, leg. 779. 
En 1801, el 23 de octubre, hay una carta de la Real Audiencia de Cuba al Consejo de Indias, en la que su presidente, el gobernador de La Habana, comunica la entrega de la parte española de la isla a Francia y solicita que sea la Audiencia quien decida a quién debía deferirse la apelación de las sufragáneas en lugar de la silla metropolitana extinguida.

La Audiencia, de acuerdo con el fiscal, el día 6 del mismo mes había decidido y comunicado a los sufragáneos que hasta que lo resolviese Su Majestad "debía otorgarse parecer ante el Obispo más inmediato al que sentencie la primera instancia" conforme a la Bula de Gregorio XIII de febrero de 1578, "pues delegándose en éstos las funciones apostólicas en caso de ser necesaria tercera instancia para causar ejecutoria con dos sentencias conformes o apelándose del metropolitano en la primera, parece concertáneo" (sic), acordado que vacando la metrópoli eclesiástica que mientras Su Majestad resuelve como Patrono Universal de las Iglesias de aquellos dominios, "se observe la parte prevenida para las ocurrencias de los enunciados impedimentos temporales". La decisión y comunicación era el alma de la ley 10, título 9, libro 1. de la Recopilación de las Leyes de Indias (22).

El Consejo en consulta a la que asisten Pedro Muñoz de la Torre, Antonio Josef Magino, Miguel Calisto de Acedo, Josef de Rojas y Antonio Porcel, y en vista de lo referido y del dictamen del fiscal, aprueba y acuerda en 30 de abril lo determinado por la Audiencia de Cuba. El Rey, el 13 de julio de 1802 resuelve que se cumpla.

Por las mismas fechas, el 6 de julio llega a la Cámara de Indias una Real Orden expedida por el Ministerio de Gracia y Justicia, de que habiéndose entregado la parte española de Santo Domingo a Francia, había llegado el caso de señalar silla metropolitana y que el Rey quería que el Consejo le consultase sobre si sería conveniente destinar todos los sufragáneos al arzobispado de México o destinar algunos al de Santa Fé.

La cámara en su vista, y de acuerdo con el dictamen del fiscal del Consejo, considera oportuno dividir las sufragáneas de Santo Domingo entre México y Santa Fe. Atendiendo a las distancias a que quedarían del arzobispado de México serían los obispados de La Habana, Cuba, Puerto Rico y Luisiana; y del arzobispado de Santa Fé los de Caracas y Guayana.

(22) Recopilación de leyes... 